\title{
The Influence of Intellectual Intelligence, Emotional Intelligence and Spiritual Intelligence on Understanding Magnitude of Behavioral Accounting
}

\author{
Purweni Widhianningrum \\ Program Studi Pendidikan Akuntansi, Universitas PGRI Madiun \\ weni.widhi@gmail.com
}

\begin{abstract}
This study aimed to examine the effect of intellectual, emotional and spiritual quotient to the level of understanding behavioral accounting. This population are Accounting Education students who are taking a behavioral accounting class, amounted to 87 students. Purposive sampling was done to sampling technique, so the total sample used are 81 respondents. Data analysis method used is multiple regression. The results showed that among the intellectual, emotional, and spiritual quotient which is owned accounting student, there only intellect quotient that is positive and significant impact on the level of understanding of behavioral accounting. This indicates that the level of understanding of behavioral accounting at the undergraduate program is still on the cognitive aspects. Thus, accounting behavioral simply understood as a method should be implemented and applied when they were faced with a condition that requires make a logical reasoning of all the problems in the field of accounting.
\end{abstract}

Keywords: intellectual quotient, emotional quotient and spiritual quotient, and behavioral accounting

\begin{abstract}
Abstrak: Penelitian ini bertujuan untuk menguji pengaruh kecerdasan intelektual, emosional dan spiritual terhadap tingkat pemahaman akuntansi keperilakuan. Populasi penelitian ini adalah mahasiswa Program Studi Pendidikan Akuntansi yang sedang menempuh mata kuliah akuntansi keperilakuan sejumlah 87 mahasiswa. Teknik pengambilan sampel dilakukan dengan purposive sampling sehingga total sampel yang digunakan sejumlah 81 responden. Teknik pengumpulan data dilakukan dengan kuesioner. Metode analisis data yang digunakan adalah regresi berganda. Hasil penelitian menunjukkan bahwa diantara kecerdasan intelektual, kecerdasan emosional, dan kecerdasan spiritual yang dimiliki mahasiswa akuntansi, hanya kecerdasan intelektual yang berpengaruh positif dan signifikan terhadap tingkat pemahaman akuntansi keperilakuan. Hal ini menunjukkan bahwa tingkat pemahaman akuntansi keperilakuan pada strata satu masih dalam ranah kognitif saja. Sehingga akuntansi keperilakuan hanya dipahami sebagai sebuah metode yang harus dilaksanakan dan diterapkan ketika dihadapkan pada suatu kondisi yang mengharuskan mahasiswa membuat sebuah penalaran logis dari segala permasalahan dalam bidang akuntansi yang terjadi akhirakhir ini.
\end{abstract}

Kata Kunci: kecerdasan intelektual, kecerdasan emosional, kecerdasan spiritual dan akuntansi keperilakuan

Pendidikan merupakan proses pengubahan sikap dan tata laku seseorang atau kelompok orang dalam usaha mendewasakan manusia melalui upaya pengajaran dan pelatihan (Kamus Besar Bahasa Indonesia, 2016). Sistem Pendidikan Nasional di Indonesia dirancang untuk mengembangkan potensi peserta didik agar menjadi manusia yang beriman dan bertakwa 
kepada Tuhan Yang Maha Esa, berakhlak mulia, sehat, berilmu, cakap, kreatif, mandiri, dan menjadi warga Negara yang demokratis serta bertanggung jawab (UU RI, 2003). Dalam rangka menghasilkan manusia yang utuh sebagaimana yang diharapkan oleh pendidikan nasional, maka kualitas pembelajaran dapat ditingkatkan tidak hanya melalui kecerdasan intelektual saja namun juga mengembangkan ketrampilan dasar lainnya (Mulyasa, 2010:162).

Selama ini, pendidikan di Indonesia, mulai dari sekolah dasar sampai perguruan tinggi, selalu menekankan pada aspek akademik, kecerdasan otak atau kecerdasan intelektual saja (Baharuddin dan Wahyuni, 2010:157). Akan tetapi intelegensi bukan satu-satunya factor yang menentukan sukses tidaknya kehidupan seseorang. Karena kehidupan merupakan suatu hal yang kompleks dan tergantung pada kehendak, pribadi serta kesempatan yang ada (Purwanto, 2013: 59). Keberhasilan antarpribadi yang berasal dari kecerdasan emosional akan menjadi salah satu ketrampilan paling penting dalam menambah kedalaman serta kekayaan kehidupan seseorang (Riyanto, 2010:260). Melalui kecerdasan emosi diharapkan semua unsur yang terlibat dalam pendidikan dan pembelajaran dapat memahami diri dan lingkungannya secara tepat, memiliki rasa percaya diri, tidak iri hati, dengki, cemas, takut, murung, tidak mudah putus asa, dan tidak mudah marah (Mulyasa, 2010:162). Menurut Baharuddin dan Wahyuni (2010), peran sentral di dalam proses belajar adalah kemampuan siswa dalam mencapai tingkat ketajaman 'mata hati' dan jiwa yang damai. Keduanya merupakan titik penentu dari kecerdasan spiritual.

Pendidikan akuntansi khususnya pendidikan tinggi akuntansi yang diselenggarakan di perguruan tinggi ditujukan untuk mendidik mahasiswa agar dapat menjadi sebagai seorang Akuntan Profesional yang memiliki pengetahuan yang menyeluruh di bidang akuntansi. Namun, mahasiswa terbiasa dengan pola belajar menghafal tetapi tidak memahami pelajaran sehingga mahasiswa akan cenderung mudah lupa dengan apa yang pernah dipelajari atau kesulitan untuk memahami apa yang diajarkan selanjutnya (Herli, Kamaliah, dan Silvi, 2014). Kuliah dan pekerjaan merupakan dua hal yang saling berkaitan. Banyak mahasiswa menempuh jalur kuliah untuk mendapatkan titel kesarjanaan dan pada akhirnya titel kesarjanaan tersebut digunakan untuk memenuhi salah satu syarat untuk dapat bekerja di suatu perusahaan. Bahkan banyak pencari kerja yang mengeluh karena banyak mahasiswa yang memiliki Indeks Prestasi Kumulatif (IPK) yang tinggi tetapi kepribadiannya kurang (Tjun Tjun, Setiawan, dan Setiana, 2009).

Salah satu faktor yang mendukung keberhasilan progam studi akuntansi adalah sikap dan mental mahasiswa dalam mengembangkan kepribadiannya yang dituntut untuk memiliki 
kemampuan dalam pemahaman ilmu akuntansi (Herli, Kamaliah, dan Silvi, 2014). Karena kesuksesan hidup, karya dan kerja sangat ditentukan oleh faktor sikap serta perilaku dalam menjalin relasi yang positif dan konstruktif dengan orang disekitarnya. Oleh karenanya, kecerdasan intelektual menjadi sangat rapuh apabila tidak diimbangai dengan kecerdasan spiritual yang baik (SQ) serta kecerdasan berelasi (EQ) (Tu'u, 2011:64).

Studi empiris terdahulu berhasil membuktikan bahwa kecerdasan intelektual (Ardana, Aritonang dan Dermawan, 2013 ;Herli, Kamaliah, dan Silvi, 2014; Artana, Herawati dan Atmadja, 2014), kecerdasan emosional (Heriningsi, Suryaningsum dan Windyastuti, 2005; Tjun Tjun, Setiawan, dan Setiana, 2009; Nasution, 2009; Hariyoga dan Suprianto, 2011; Herli, Kamaliah, dan Silvi, 2014; Ariantini, Sujana, dan Herawati, 2014; Artana, Herawati dan Atmadja, 2014) dan spiritual (Herli, Kamaliah, dan Silvi, 2014; Khaerani dan Agung, 2014) berpengaruh signifikan terhadap tingkat pemahaman akuntansi. Menurut Hariyoga dan Suprianto (2011), seorang mahasiswa dengan kecerdasan emosional yang tinggi akan berdampak positif pada dirinya dengan mencapai tingkat graduate intelegensi dalam mengolah suatu proses ilham kehidupan dari berbagai aspek bidang. Spiritual memiliki kekuatan untuk mentransformasi kehidupan dan bahkan dapat mengubah realitas kehidupan fisik di sekitar kita. Dengan memiliki kecerdasan spiritual berarti kita memahami sepenuhnya makna dan hakikat kehidupan yang kita jalani dan ke manakah kita akan pergi. Menjadi cerdas spiritual berarti kita lebih memahami diri kita sebagai makhluk spiritual yang murni, penuh kasih, suci, dan memiliki semua sifat-sifat Ilahi (Solikin, 2013).

Berdasarkan uraian di atas, penelitian ini bertujuan untuk menguji pengaruh kecerdasan intelektual, emosional dan spiritual terhadap tingkat pemahaman akuntansi keperilakuan. Kontribusi penelitian ini diharapkan dapat dijadikan sebagai bahan pemikiran bagi pihak pengelola Perguruan Tinggi di Indonesia untuk lebih memprioritaskan kualitas lulusan yang berakhlak mulia, khususnya mahasiwa akuntansi melalui upaya konsisten dalam membangun, mengembangkan dan memelihara potensi diri mahasiswa tidak hanya dalam kecerdasan intelegensi saja, namun juga kecerdasan emosional dan spiritual.

\section{Tingkat Pemahaman Akuntansi}

Pemahaman merupakan kemampuan yang umumnya mendapat penekanan dalam proses belajar-mengajar. Peserta didik dituntut memahami atau mengerti apa yang diajarkan, mengetahui apa yang sedang dikomunikasikan dan dapat memanfaatkan isinya tanpa 
keharusan menghubungkannya dengan hal-hal lain (Daryanto, 2010:106). Pendidikan bukan hanya sekedar membuat peserta didik mengetahui tentang ilmu pengetahuan, teknologi, seni serta mampu mengembangkannya, namun juga mengembangkan dan menumbuhkan potensi diri para peserta didik secara optimal kearah yang positif (Pidarta, 2007:11). Assesment merupakan keluasan dan kedalaman belajar peserta didik baik secara kuantitatif maupun kualitatif (Syah, 2013:140). Dan belajar merupakan perubahan perilaku sebagai hasil dari pengalaman. Dengan kata lain, bahwa belajar adalah suatu cara mengamati, membaca, meniru, mencoba sesuatu, mendengar, dan mengikuti arah tertentu (Cronbach dalam Riyanto, 2010:5).

Pendidikan dan pengajaran akuntansi tidak hanya membatasi pada apa yang nyatanya dipraktikkan (aspek teknis) tetapi juga memasukkan alternative-alternatif dan penalarannya sehingga peserta didik nantinya dapat menerapkan gagasan altenatif yang menuju ke perbaikkan praktik (Suwardjono, 2014:5). Karena akuntansi pada dasarnya dirancang untuk memenuhi kebutuhan praktis (Lubis, 2010:3) dalam sebuah proses pengidentifikasian, pengukuran, dan pengomunikasian informasi ekonomi yang bersifat keuangan (Belkaoui, 2011:50). Informasi yang berupa laporan keuangan tersebut kemudian digunakan oleh pihakpihak yang berkepentingan untuk melakukan prediksi kinerja entitas di masa mendatang (Martani, 2012:4). Sebagai suatu sistem informasi, keberhasilan akuntansi tentu tidak lepas dari perilaku manusia selaku pemakai dan yang memberikan respon (Suartana, 2010:3). Disiplin ilmu akuntansi yang berorientasi pada bagaimana perilaku manusia secara langsung mempengaruhi data akuntansi dan keputusan bisnis, serta bagaimana akuntansi mempengaruhi keputusan bisnis dan perilaku manusia disebut dengan akuntansi keperilakuan (Lubis, 2010:29).

\section{Kecerdasan Intelektual}

Manusia merupakan makhluk ciptaan Tuhan yang paling sempurna dan mulia di dunia ini, karena sempurna itulah manusia dikaruniai berbagai potensi yang luar biasa di antaranya adalah kecerdasan intelektual. Kecerdasan intelektual merupakan potensi dasar manusia dan merupakan faktor genetik. Semakin kecerdasan intelektual seseorang semakin tinggi pula orang tersebut menunjukkan kemampuannya (Riyanto, 2010:251). Pola pikir melalui kecerdasan intelektual mengindikasikan dominasi rasionalitas yang juga mengimplikasikan dominasi rasio atau nalar dalam kehidupan (Baharuddin dan Wahyuni, 2010:157). 
Kecerdasan intelektual merupakan mental intelektual yang meruang lingkupi aktivitas-aktivitas pembelajaran, koneksi, pengkategorian, pengenalan, idenfikasi, menganalisis, rasionalisasi, perhitungan, daya kritis dan berpikir strategis. Intelektualitas penting untuk mengendalikan diri manusia, agar tidak hanya dikuasai oleh emosional dan perasaan, tetapi saat tertentu mampu mengadakan perhitungan-perhitungan yang realistis terhadap suatu keputusan (Jarob, 2011:37). Kecerdasan ini dimiliki oleh setiap individu untuk mengenal kembali, memahami, mengaplikasi, menganalisis, memadukan, dan mengevaluasi lingkungan sekitarnya (Mudyahardjo, 2010:94).

\section{Kecerdasan Emosional}

Menurut Agustian (2004), kecerdasan emosional merupakan kemampuan mengendalikan emosi serta penguasaan diri untuk mengambil keputusan dalam kondisi yang tenang. Goleman (2005:512) mendefinisikan kecerdasan emosional sebagai sebuah kemampuan mengenali perasaan diri sendiri dan perasaan orang lain, memotivasi diri sendiri, serta mengelola emosi dengan baik pada diri sendiri dan dalam hubungan dengan orang lain. Keberhasilan antarpribadi yang berasal dari kecerdasan emosional akan menjadi salah satu ketrampilan paling penting dalam abad ke-21. Emosi menambah kedalaman dan kekayaan dalam kehidupan. Tanpa perasaan tindakan seseorang akan lebih menyerupai komputer, berpikir tetapi tanpa gairah (Riyanto, 2010:260).

Dalam dunia pendidikan, kecerdasan emosional yang baik dapat membantu pada peserta didik menjadi: a) jujur, disiplin, dan tulus pada diri sendiri, membangun kekuatan dan kesadaran diri, mendengarkan suara hati, hormat dan tanggung jawab; b) memantapkan diri, maju terus, ulet, dan membangun inspirasi secara berkesinambungan; c) membangun watak dan kewibawaan, meningkatkan potensi, dan mengintegrasikan tujuan belajar ke dalam tujuan hidupnya, d) memanfaatkan peluang dan menciptakan masa depan yang lebih cerah (Mulyasa, 2010:162).

\section{Kecerdasan Spiritual}

Kecerdasan spiritual sebagai kecerdasan manusia yang bersumber dari Allah dengan unsur-unsur sifat Tuhan atau God-Spot, menjadikan manusia memiliki ketangguhan pribadi dan ketangguhan sosial dalam mewujudkan kesuksesan manusia (Agustian, 2001). Sehingga kecerdasan spiritual menyebabkan manusia mengakui dalam dirinya adanya kuasa lain, atau unsur rohaniah seseorang (Jarob, 2011). Kecerdasan spiritual bertumpu pada bagian dalam diri manusia yang berhubungan dengan kearifan di luar ego atau jiwa sadar. Ini adalah kecerdasan yang digunakan bukan hanya untuk mengetahui nilai-nilai yang ada, melainkan 
juga untuk secara kreatif menemukan nilai-nilai baru (Zohar dan Marshal, 2001). Seseorang dengan kecerdasan spiritual yang tinggi memiliki kecenderungan menjadi seorang pemimpin yang penuh pengabdian, bertanggung jawab untuk membawakan visi dan nilai yang lebih tinggi kepada orang lain (Baharuddin dan Wahyuni, 2010:165).

Zohar dan Marshall (2002) mengungkapkan bahwa kecerdasan spiritual terdiri dari dimensi-dimensi sebagai berikut: (a) kemampuan bersikap fleksibel yaitu dapat menempatkan diri dan menerima pendapat orang lain secara terbuka; (b) tingkat kesadaran yang tinggi seperti kemampuan autocritism dan mengerti tujuan serta visi hidupnya; (c) kemampuan untuk menghadapi dan memanfaatkan hal-hal yang menyulitkan yang ditandai dengan tidak adanya penyesalan, tetap tersenyum, dan bersikap tenang; (d) kemampuan menghadapi dan menyembuhkan rasa sakit yang ditandai dengan munculnya sikap ikhlas dan pemaaf; (e) kualitas hidup yang diilhami oleh visi dan nilai-nilai seperti prinsip dan pegangan hidup dan berpijak pada kebenaran; (f) keengganan untuk menyebabkan kerugian yang tidak perlu misalnya menunda pekerjaan dan cenderung untuk berpikir sebelum bertindak; $(\mathrm{g})$ kecenderungan melihat keterkaitan antara berbagai hal atau memiliki pandangan yang holistik yakni mampu untuk berpikir secara logis dan berlaku sesuai dengan norma sosial; (h) kecenderung menanyakan "mengapa" atau "bagaimana" jika akan mencari jawaban-jawaban yang mendasar dan memiliki kemampuan untuk berimajinasi, serta memiliki rasa ingin tahu yang tinggi; (i) mudah untuk bekerja melawan konvensi (adat dan kebiasaan sosial), seperti mau memberi dan tidak mau menerima.

\section{Pengaruh Kecerdasan Intelektual Terhadap Tingkat Pemahaman Akuntansi}

Studi empris yang dilakukan oleh Ardana, Aritonang dan Dermawan (2013), Herli, Kamaliah, dan Silvi (2014) dan Artana, Herawati dan Atmadja (2014) membuktikan bahwa kecerdasan intelektual berpengaruh signifikan terhadap tingkat pemahaman akuntansi. Menurut Ardana, Aritonang dan Dermawan (2013), prestasi belajar mahasiswa S1 Akuntansi seharusnya mencerminkan kompetensi yang mencakup penguasaan ilmu atau pengetahuan akuntansi dan perpajakan serta disiplin lain yang terkait (domain kognitif), keterampilan (skill) dalam mencatat, menyajikan, menganalisis, mengaudit laporan keuangan, menggunakan komputer, keterampilan berkomunikasi, dan sebagainya (domain psikomotorik), serta mematuhi standar sikap dan perilaku (attitude and behavior) yang diatur dalam kode etik profesi akuntansi (domain afeksi). Aspek kognitif dilandasi oleh kecerdasan intelektual, aspek psikomotori erat kaitannya dengan kesehatan fisik, aspek sikap dan 
perilaku erat kaitannya dengan kecerdasan emosional dan kecerdasan spiritual. Berdasarkan uraian di atas, maka hipotesis penelitian dapat dirumuskan sebagai berikut:

$\mathrm{H}_{1}$ : Kecerdasan intelektual berpengaruh positif dan signifikan terhadap tingkat pemahaman akuntansi keperilakuan

\section{Pengaruh Kecerdasan Emosional Terhadap Tingkat Pemahaman Akuntansi}

Studi empiris yang dilakukan oleh Heriningsih, Suryaningsum dan Windyastuti (2005), Tjun Tjun, Setiawan, dan Setiana (2009), Nasution (2009), Hariyoga dan Suprianto (2011); Herli, Kamaliah, dan Silvi (2014), Ariantini, Sujana, dan Herawati (2014), dan Artana, Herawati dan Atmadja (2014) membuktikan bahwa kecerdasan emosional berpengaruh signifikan terhadap tingkat pemahaman akuntansi. Mahasiswa tanpa kecerdasan emosional tidak akan mampu untuk mengelola emosinya dan tidak mampu memberikan motivasi didalam dirinya. Sifat lain yang dapat mendukung mahasiswa memahami akuntansi adalah kepercayaan diri, dimana mahasiswa yang memiliki sikap percaya diri tinggi akan mampu untuk mengungkapkan pendapatnya (Ariantini, Sujana, dan Herawati, 2014). Dalam kehidupan akademik, tampaknya kecerdasan emosional juga memiliki peranan besar. Untuk menjadi seorang sarjana, dibutuhkan proses yang panjang, usaha yang keras dan dukungan dari berbagai pihak. Proses ini akan mempengaruhi pengalaman hidup mahasiswa (Heriningsih, Suryaningsum dan Windyastuti, 2005). Berdasarkan uaraian di atas, maka hipotesis penelitian dapat dirumuskan sebagai berikut:

$\mathrm{H}_{2}$ : Kecerdasan emosional berpengaruh positif dan signifikan terhadap tingkat pemahaman akuntansi keperilakuan

\section{Pengaruh Kecerdasan Spiritual Terhadap Tingkat Pemahaman Akuntansi}

Studi empiris Herli, Kamaliah, dan Silvi (2014) dan Khaerani dan Agung (2014) membuktikan bahwa kecerdasan spiritual berpengaruh signifikan terhadap tingkat pemahaman akuntansi. Kecerdasan spiritual merupakan kecerdasan ruhaniah, kecerdasan hati, dan kecerdasan jiwa yang membantu kita menyembuhkan serta membangun diri kita secara utuh. Kecerdasan spiritual akan mengembalikan manusia kepada makhluk spiritual, yang merupakan fitrahnya (Baharuddin dan Wahyuni, 2010:162). Seseorang yang memiliki hubungan yang baik secara vertical terhadap Tuhan dan memandang agama mengandung suatu kebenaran akan cenderung untuk menjaga perilakunya pada hubungan secara horizontal (Widyastuti dan Ludigdo, 2010:149). Spritual mahasiswa akuntansi yang cerdas akan mampu membantu dalam pemecahan permasalahan - permasalahan dalam memahami akuntansi sehingga mahasiswa dapat bersikap tenang dalam menghadapi masalah - masalah dalam 
proses pemahaman akuntansi (Khaerani dan Agung, 2014). Berdasarkan uaraian di atas, maka hipotesis penelitian dapat dirumuskan sebagai berikut:

$\mathrm{H}_{3}$ : Kecerdasan spiritual berpengaruh positif dan signifikan terhadap tingkat pemahaman akuntansi keperilakuan

\section{METODE}

Populasi penelitian ini adalah mahasiswa Program Studi Pendidikan Akuntansi yang sedang menempuh mata kuliah akuntansi keperilakuan sejumlah 87 mahasiswa. Teknik pengambilan sampel dilakukan dengan purposive sampling, dimana responden merupakan mahasiswa angkatan 2013 dan belum pernah menempuh mata kuliah akuntansi keperilakuan. Total sampel yang digunakan dalam penelitian ini adalah 81 responden.

Jenis data yang digunakan dalam penelitian ini adalah data primer yang diperoleh melalui survey, dengan cara menyebarkan kuesioner secara langsung kepada mahasiswa S1 Program Studi Pendidikan Akuntansi, Fakultas Pendidikan Ilmu Pengetahuan Sosial IKIP PGRI Madiun. Penelitian ini menggunakan skala Likert, yang terdiri dari empat pilihan jawaban atas pernyataan yang diajukan sehingga menjadi selalu diberi skor 4 , sering diberi skor 3, jarang diberi skor 2 dan tidak pernah diberi skor 1 .

\section{Tabel 1 Definisi Operational Variabel}

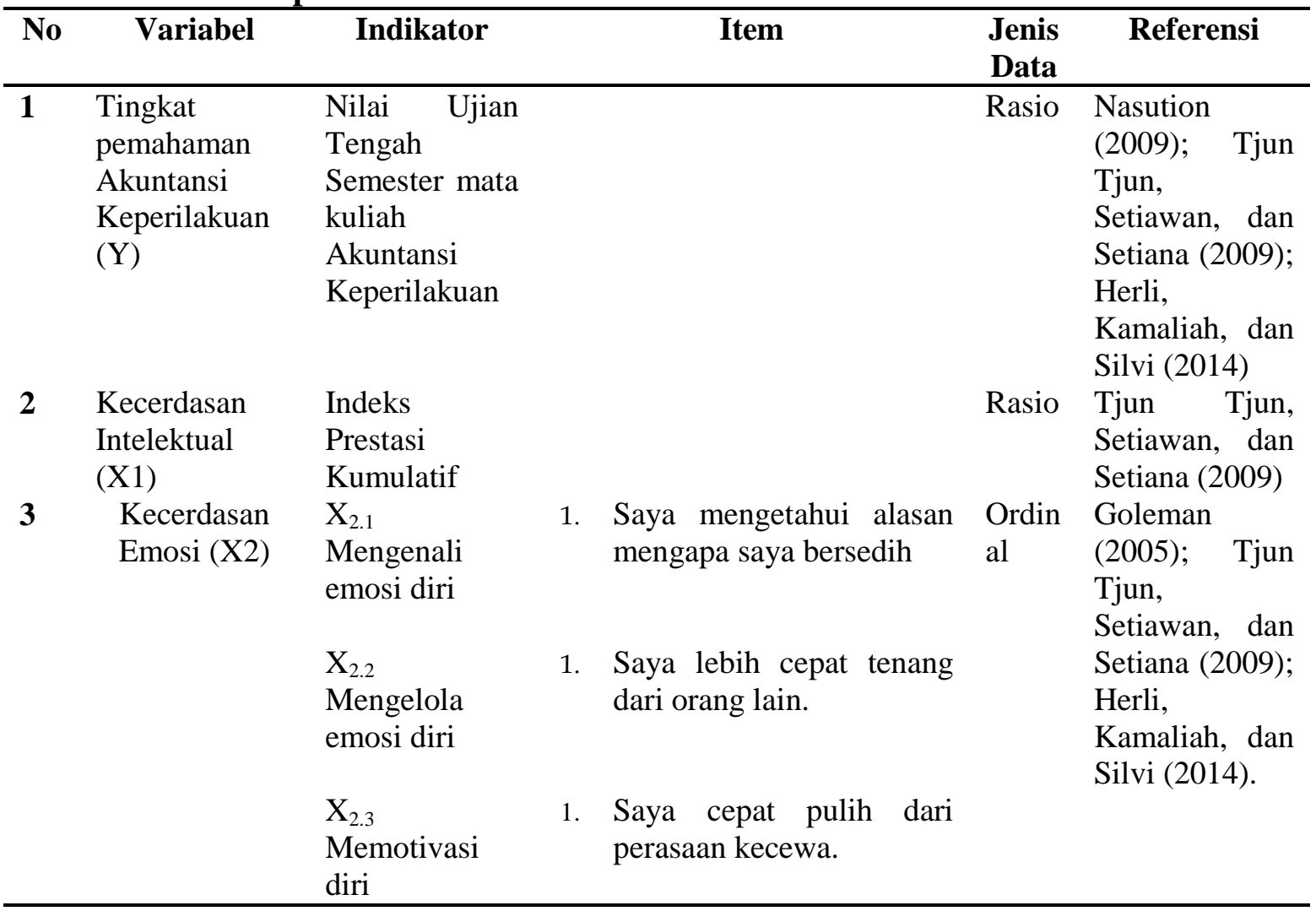




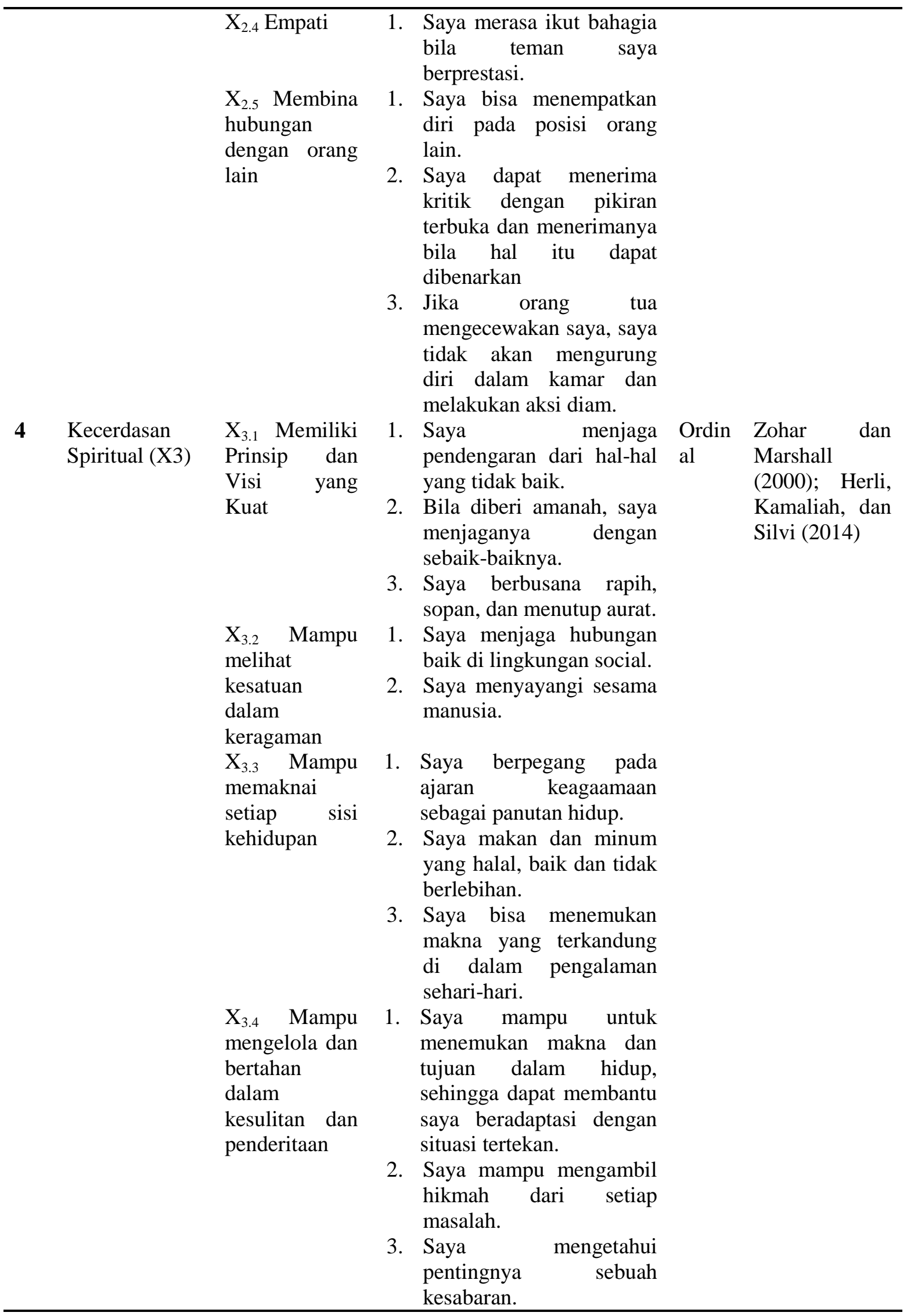


Kerangka konsep dalam penelitian ini menjelaskan bahwa tingkat pemahaman akuntansi keperilakuan dipengaruhi oleh variabel kecerdasan intelektual, kecerdasan emosional, dan kecerdasan spiritual seperti yang disajikan dalam gambar berikut ini:

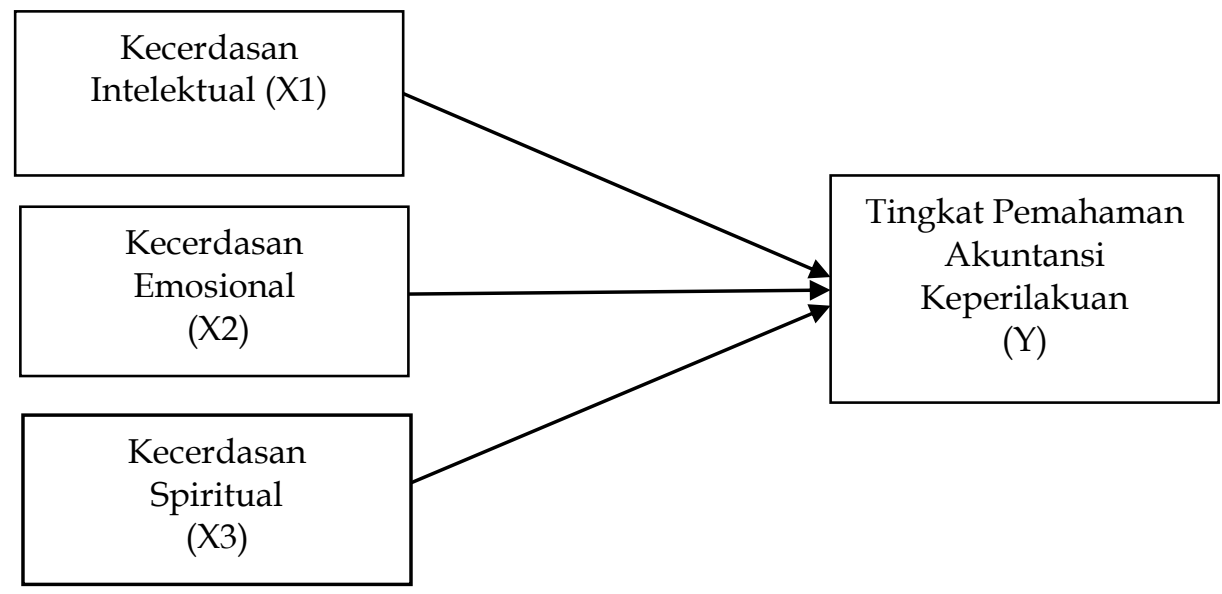

Gambar 1

Berdasarkan desain penelitian di atas, maka diajukan hipotesis penelitian sebagai berikut:

$\mathbf{H}_{1}$ : Kecerdasan intelektual berpengaruh positif dan signifikan terhadap Tingkat pemahaman akuntansi keperilakuan.

$\mathbf{H}_{2}$ : Kecerdasan emosional berpengaruh positif dan signifikan terhadap Tingkat pemahaman akuntansi keperilakuan.

$\mathbf{H}_{3}$ : Kecerdasan spiritual berpengaruh positif dan signifikan terhadap Tingkat pemahaman akuntansi keperilakuan.

Model empiris yang digunakan dalam penelitian ini adalah model regresi berganda, dengan alat analisis SPSS versi 20.0. Bentuk dari model regresi berganda dalam penelitian ini adalah sebagai berikut:

$$
\mathrm{Y}=\beta_{0}+\beta_{1} \mathrm{X}_{1}+\beta_{2} \mathrm{X}_{2}+\beta_{3} \mathrm{X}_{3}+\varepsilon
$$

Keterangan:

$$
\begin{array}{ll}
\mathrm{Y} & =\text { Tingkat Pemahaman Akuntansi Keperilakuan } \\
\beta_{0} & =\text { Konstanta } \\
\beta_{1 \ldots \ldots . .} \beta_{4} & =\text { Koefisien Regresi } \\
\mathrm{X}_{1} & =\text { Kecerdasan Intelektual } \\
\mathrm{X}_{2} & =\text { Kecerdasan Emosional } \\
\mathrm{X}_{3} & =\text { Kecerdasan Spiritual }
\end{array}
$$


$\varepsilon \quad=$ error $($ kesalahan residu)

\section{HASIL dan PEMBAHASAN}

\section{HASIL}

\section{Uji Validitas Dan Reliabilitas}

Uji validitas dan reliabilitas pada penelitian yang dilakukan terhadap 81 responden menunjukkan bahwa seluruh ítem pernyataan valid dan reliabel. Masing-masing item variabel dapat dikatakan reliabel apabila mempunyai nilai angka Alpha $\geq 0,6$.

\section{Uji Normalitas}

Adanya normalitas dapat dideteksi dengan melihat penyebaran data (titik) pada sumbu diagonal dari grafik.

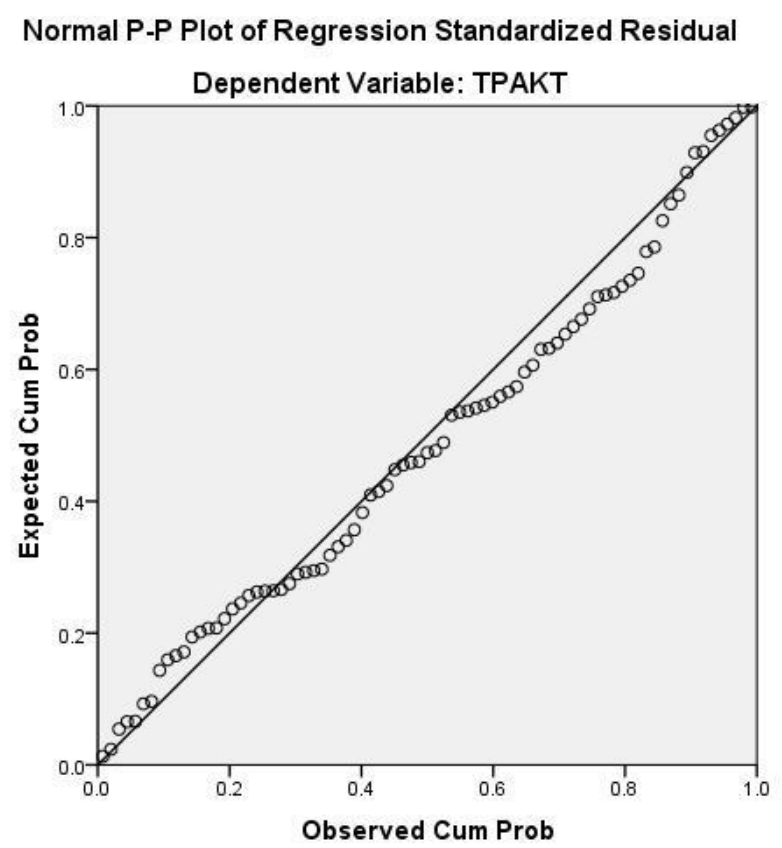

Gambar 2

Pada gambar 2 terlihat bahwa titik-titik mendekati atau menyentuh garis diagonalnya yang berarti data telah berdistribusi normal sehingga proses pengujian data selanjutnya dapat dilakukan.

\section{Uji Multikolineritas}

Untuk mendeteksi keberadaan multikolinearitas dilakukan dengan melihat nilai Variance Inflation Factor (VIF) atau tolerance value. Nilai cutoff yang umum dipakai untuk menunjukkan adanya multikolineritas adalah apabila tolerance value kurang dari 0.10 atau 
nilai Variance Inflation Factor (VIF) lebih dari 10 (Ghozali, 2006:91-92). Hasil uji multikolineritas disajikan pada tabel 3 berikut:

\section{Tabel 3 Hasil Uji Multikolineritas}

\begin{tabular}{clcc}
\hline No & \multicolumn{1}{c}{ Variabel } & Tolerance & VIF \\
\hline 1. & Kecerdasan Intelektual $\left(\mathrm{X}_{1}\right)$ & .964 & 1.037 \\
2. & Kecerdasan Emosional $\left(\mathrm{X}_{2}\right)$ & .797 & 1.255 \\
3. & Kecerdasan Spiritual $\left(\mathrm{X}_{3}\right)$ & .824 & 1.214 \\
\hline
\end{tabular}

Sumber: data diolah

Hasil perhitungan nilai Variance Inflation Factor (VIF) menunjukkan tidak ada satu variabel independen yang memiliki nilai tolerance value lebih dari 0.10 dan nilai VIF lebih dari 10. Jadi dapat disimpulkan bahwa tidak ada multikolineritas antar variabel independen dalam model regresi.

\section{Uji Heterokedastisitas}

Untuk mendeteksi ada tidaknya heterokedastisitas adalah dengan melihat ada tidaknya pola tertentu pada grafik scatterplot antara SREID dan ZPRED.

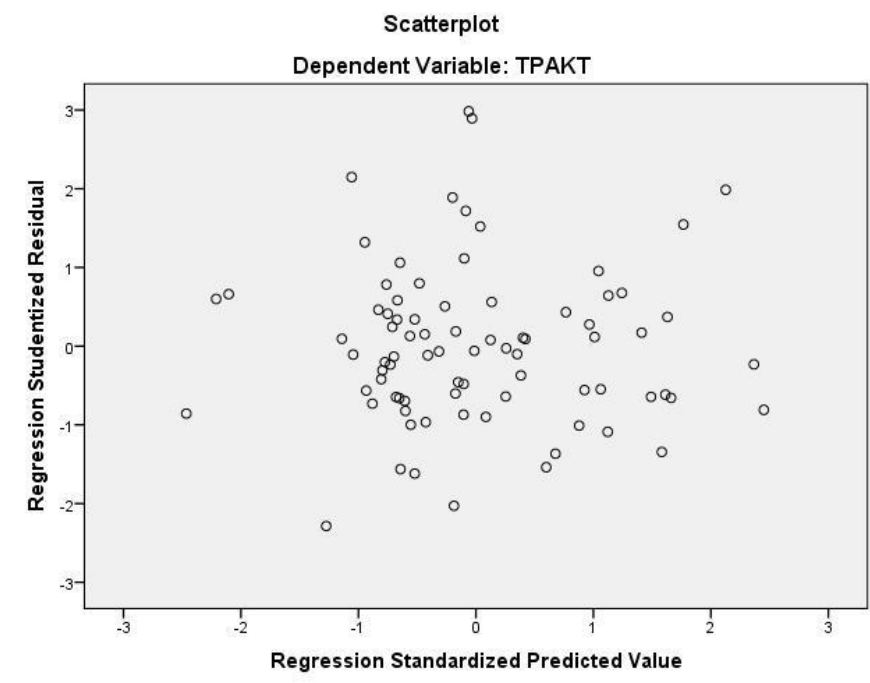

Gambar 3

Dari gambar 3 terlihat bahwa titik-titik menyebar secara acak serta baik diatas maupun dibawah angka 0 pada sumbu $\mathrm{Y}$, sehingga dapat disimpulkan bahwa tidak terjadi heterokedastisitas pada model regresi yang digunakan.

\section{Uji Autokorelasi}

Uji yang digunakan untuk menguji adanya autokorelasi dalam suatu model regresi dapat dilakukan dengan melihat nilai durbin watson. 
Tabel 3 Hasil Uji Autokorelasi

\begin{tabular}{ccccc}
\hline & Du & DW & 4-du & Interprestasi \\
\hline Nilai & 1.575 & 1.959 & 2.425 & Tidak ada Autokorelasi \\
\hline
\end{tabular}

Sumber: data diolah

Pada tabel 4 diatas, diperoleh nilai durbin watson sebesar 1.959 lebih besar dari tingkat batas atas (du) 1.575 dan kurang dari 2.425 (4-du), maka dapat disimpulkan bahwa tidak terjadi autokorelasi pada model regresi yang akan digunakan.

\section{Pengujian Hipotesis}

Tabel 4 Rangkuman Hasil Analisis Regresi

\begin{tabular}{lcc}
\hline \multicolumn{1}{c}{ Variabel Independen } & Koefisien Regresi & Prob sig \\
\hline Kecerdasan Intelektual $\left(\mathrm{X}_{1}\right)$ & 25.451 & $0.000^{*}$ \\
Kecerdasan Emosional $\left(\mathrm{X}_{2}\right)$ & 0.211 & 0.528 \\
Kecerdasan Spiritual $\left(\mathrm{X}_{3}\right)$ & 0.294 & 0.263
\end{tabular}

Adj $\mathrm{R}^{2} \quad: 0.363$

Konstanta : -25.238

Sumber: data diolah

Dari tabel di atas, terlihat bahwa ketiga variabel independen yang dimasukkan dalam model ternyata tidak semuanya signifikan, hanya variabel Kecerdasan Intelektual $\left(\mathrm{X}_{1}\right)$ yang signifikan dengan nilai probabilitas sebesar 0.000. Dengan melihat koefisien regresi, maka dapat dibuat persamaan (model) regresi sebagai berikut:

$$
Y=-25.238+25.451 X_{1}+0.211 X_{2}+0.294 X_{3}
$$

Nilai konstanta sebesar -25.238 menunjukkan bahwa jika mahasiswa pendidikan akuntansi tidak menggunakan kecerdasan intelektual, kecerdasan emosional dan kecerdasan spiritual dalam proses pembelajaran, maka tingkat pemahaman akuntansi keperilakuan sebesar -25.238. Koefisien regresi 25.451 menunjukkan bahwa setiap peningkatan satu satuan kecerdasan intelektual maka tingkat pemahaman akuntansi keperilakuan akan meningkat sebesar 25.451 satuan. Koefisien regresi 0.211 menunjukkan bahwa setiap peningkatan satu satuan kecerdasan emosional maka $\mathrm{k}$ tingkat pemahaman akuntansi keperilakuan akan meningkat sebesar 0.211 satuan. Koefisien regresi 0.294 menunjukkan bahwa setiap peningkatan satu satuan kecerdasan spiritual maka tingkat pemahaman akuntansi keperilakuan akan meningkat sebesar 0.294 satuan.

\section{PEMBAHASAN}

\section{Pengaruh Kecerdasan Intelektual Terhadap Tingkat Pemahaman Akuntansi}

\section{Keperilakuan}

Pengaruh variabel kecerdasan intelektual menunjukkan arah hubungan positif dan signifikan terhadap tingkat pemahaman akuntansi keperilakuan. Hasil tersebut terlihat dari 
besarnya nilai koefisien regresi sebesar 25.451 dengan tingkat signifikansi sebesar 0.000 . Dengan demikian dapat disimpulkan bahwa Hipotesis 1 yang menyatakan bahwa kecerdasan intelektual berpengaruh positif dan signifikan terhadap tingkat pemahaman akuntansi keperilakuan, diterima. Hasil penelitian ini memberikan bukti empiris bahwa kecerdasan intelektual yang dimiliki setiap mahasiwa mampu meningkatkan tingkat pemahaman akuntansi keperilakuan. Hasil ini konsisten dengan studi empiris terdahulu yang dilakukan oleh Ardana, Aritonang dan Dermawan (2013), Herli, Kamaliah, dan Silvi (2014) dan Artana, Herawati dan Atmadja (2014). Pada dasarnya kecerdasan intelektual mencakup kemampuankemampuan tentang pemahaman verbal, ketrampilan numerik, kemampuan menalar, pemahaman ruang dan kefasihan menggunakan kata (Mudyaharjo, 2010:93). Akuntansi erat kaitannya dengan proses pengidentifikasian, pengukuran, dan pengomunikasian informasi ekonomi yang bersifat keuangan (Belkaoui, 2011:50), namun dalam aspek keperilakuan, akuntansi berhubungan dengan perilaku manusia yang terkait dengan informasi akuntansi dan segala permasalahannya (Suartana, 2010:2). Penelitian ini menunjukkan bahwa mahasiswa program studi pendidikan akuntansi FPIPS IKIP PGRI Madiun mampu menangkap, mengolah serta menarik kesimpulan dari proses pembelajaran akuntansi keperilakuan. Namun materi akuntansi keperilakuan tersebut hanya dipahami sebagai sebuah metode yang harus dilaksanakan dan diterapkan ketika dihadapkan pada suatu kondisi yang mengharuskan mahasiswa membuat sebuah penalaran logis dari segala permasalahan dalam bidang akuntansi yang terjadi akhir-akhir ini.

\section{Pengaruh Kecerdasan Emosional Terhadap Tingkat Pemahaman Akuntansi Keperilakuan}

Pengaruh variabel kecerdasan emosional menunjukkan arah hubungan positif tetapi tidak signifikan terhadap tingkat pemahaman akuntansi keperilakuan. Hasil tersebut terlihat dari besarnya nilai koefisien regresi sebesar 0.211 dengan tingkat signifikansi sebesar 0.528. Dengan demikian dapat disimpulkan bahwa Hipotesis 2 yang menyatakan bahwa kecerdasan emosional berpengaruh positif dan signifikan terhadap tingkat pemahaman akuntansi keperilakuan, ditolak. Hasil ini konsisten dengan studi empiris terdahulu yang dilakukan oleh Ardana, Aritonang dan Dermawan (2013) yang menyatakan bahwa tidak ada hubungan yang signifikan antara variabel kecerdasan emosional dengan Prestasi Belajar Mahasiswa. Hal ini dikarenakan usia mahasiswa yang masih muda dan belum mengenyam seluk beluk persoalan di dunia kerja yang penuh persaingan dan intrik sehingga belum banyak mengalami gangguan di tingkat emosional sehingga tidak berkaitan secara signifikan terhadap Prestasi Belajar 
Mahasiswa. Pada penelitian ini, responden yang digunakan adalah mahasiswa program studi pendidikan akuntansi FPIPS IKIP PGRI Madiun semester VII dengan rata-rata usia 21 tahun dan belum memiliki pengalaman bekerja sebagai akuntan. Secara psikologis, pada usia tersebut mahasiswa memiliki kecenderungan suasana hati yang tidak menentu. Sehingga selama proses pembelajaran, mahasiswa yang minim akan pengetahuan di dunia kerja tersebut menjadi kurang berkonsentrasi dalam memahami pentingnya akuntansi keperilakuan.

\section{Pengaruh Kecerdasan Spiritual Terhadap Tingkat Pemahaman Akuntansi Keperilakuan}

Pengaruh kecerdasan spiritual menunjukkan arah hubungan positif tetapi tidak signifikan terhadap tingkat pemahaman akuntansi keperilakuan. Hasil tersebut terlihat dari besarnya nilai koefisien regresi sebesar 0.294 dengan tingkat signifikansi sebesar 0.263. Dengan demikian dapat disimpulkan bahwa Hipotesis 3 yang menyatakan bahwa kecerdasan spiritual berpengaruh signifikan terhadap tingkat pemahaman akuntansi keperilakuan, ditolak. Hasil ini konsisten dengan studi empiris terdahulu yang dilakukan oleh Ardana, Aritonang dan Dermawan (2013) yang menyatakan bahwa tidak ada hubungan yang signifikan antara variabel kecerdasan spiritual dengan Prestasi Belajar Mahasiswa. Menurut Baharuddin dan Wahyuni (2010), titik kekuatan kecerdasan spiritual terletak pada berkembangnya dengan baik jiwa dan hati manusia. Dua esensi manusia tersebut apabila dikembangkan maka akan mencapai tingkat ketajaman 'mata hati', yaitu satu-satunya elemen esensi manusia yang sanggup menatap baying-bayang Tuhan yang diisyaratkan oleh alam semesta. Hati yang terlatih akan mampu mencapai tingkatan jiwa yang damai. Jiwa yang damai inilah yang kemudian memiliki peran sentral dalam proses belajar. Hasil penelitian ini membuktikan bahwa mahasiswa program studi pendidikan akuntansi IKIP PGRI Madiun sebenarnya telah memiliki prinsip dan pedoman yang jelas untuk berperilaku dalam segala aspek kehidupan. Namun hal tersebut belum sepenuhnya menjadi inspirasi serta dimaknai oleh setiap mahasiswa dalam menyikapi permasalahan yang dihadapi selama proses pembelajaran guna memudahkan dirinya memaknai akuntansi keperilakuan.

\section{SIMPULAN}

Hasil penelitian ini membuktikan bahwa diantara kecerdasan intelektual, kecerdasan emosional, dan kecerdasan spiritual yang dimiliki mahasiswa akuntansi, hanya kecerdasan intelektual yang berpengaruh positif dan signifikan terhadap tingkat pemahaman akuntansi keperilakuan. Hal ini menunjukkan bahwa tingkat pemahaman akuntansi keperilakuan pada 
mahasiswa pendidikan akuntansi IKIP PGRI Madiun masih dalam ranah kognitif saja, yang mencakup kemampuan menalar dan ketrampilan numerik. Sedangkan kemampuan mengalami dan menghayati nilai-nilai suatu hal (emosional dan spiritual) belum mampu dilaksanakan.

Hasil penelitian ini diharapkan dapat dijadikan bahan pemikiran bagi pihak pengelola Perguruan Tinggi di Indonesia untuk lebih memprioritaskan kualitas lulusan, khususnya mahasiwa akuntansi melalui upaya konsisten dalam membangun serta mengembangkan potensi diri mahasiswa tidak hanya dalam kemampuan intelegensi saja, namun juga kemampuan emosional dan spiritual. Keterbatasan dalam penelitian ini adalah bahwa sampel penelitian menggunakan responden mahasiswa semester VII yang menempuh mata kuliah akuntansi keperilakuan. Adapun saran bagi penelitian selanjutnya dapat memperluas daerah penelitian atau mengikutsertakan alumni mahasiswa akuntansi yang secara praktis telah memasuki dunia kerja sehingga diharapkan mampu mempresentasikan keadaan secara umum tentang pengaruh kecerdasan emosional, kecerdasan intelektual, kecerdasan spiritual terhadap pemahaman akuntansi keperilakuan.

\section{DAFTAR RUJUKAN}

Agustian, A.G. 2004. Rahasia Sukses Membangun Kecerdasan Emosi dan Spiritual (ESQ) Berdasarkan 6 Rukun Iman dan 5 Rukun Islam. Cetakan Kedelapanbelas. Arga, Jakarta.

Ardana, I Cenik, Lerbin R. Aritonang dan Elizabeth Sugiarto Dermawan. 2013. Kecerdasan Intelektual, Kecerdasan Emosional, Kecerdasan Spiritual, Dan Kesehatan Fisik Untuk Memprediksi Prestasi Belajar Mahasiswa Akuntansi (Studi Empiris Pada Mahasiswa Tingkat Akhir (Skripsi) S1 Akuntansi FE Untar). Jurnal Akuntansi, Volume XVII, No. 03.

Ariantini, Komang Nova, Edy Sujana, dan Nyoman Trisna Herawati. 2014. Pengaruh Kecerdasan Emosional Dan Minat Membaca Terhadap Tingkat Pemahaman Akuntansi Dengan Kepercayaan Diri Sebagai Variabel Moderasi (Studi Empiris pada Mahasiswa Jurusan Akuntansi Universitas di Bali). Jurusan Akuntansi Program S1 Ak Universitas Pendidikan Ganesha, Vol. 2, No. 1.

Baharuddin dan Esa Nur Wahyuni. 2010. Teori Belajar dan Pembelajaran. Yogyakarta: ArRuzz Media.

Belkaoui, Ahmed Riahi. 2011. Accounting Theory. Jakarta: salemba Empat.

Daryanto. 2010. Evaluasi Pendidikan. Jakarta: Rineka Cipta.

Goleman, D. 2005. Kecerdasan Emosi untuk Mencapai Puncak Prestasi. Cetakan Keenam. PT Gramedia Pustaka Utama, Jakarta. Diterjemahkan oleh Alex Tri Kuntjahyo Widodo dari Working with Emotional Intelligence, 1999.

Hariyoga, Septian dan Edy Suprianto. 2011. Pengaruh Kecerdasan Emosional, Perilaku Belajar, Dan Budaya Terhadap Tingkat Pemahaman Akuntansi Dengan Kepercayaan Diri Sebagai Variabel Pemoderasi. Simposium Nasional Akuntansi XIV Banda Aceh, 21- 22 Juli. 
Heriningsih, Sucahyo, Sri Suryaningsum, dan Windyastuti. 2005. Pengaruh Kecerdasan Emosional Pada Pemahaman Pengetahuan Akuntansi Di Tingkat Pengantar Dengan Penalaran Dan Pendekatan Sistem. JAM: Jurnal Akuntansi dan Manajemen, Vol. XVI, Nomor 2.

Herli, Fauzi, Kamaliah dan Alfiati Silvi. 2014. Pengaruh Kecerdasan Emosional, Kecerdasan Intelektual, Kecerdasan Spritual, dan Kecerdasan Sosial Terhadap Pemahaman Akuntansi. JOM FEKON Vol. 1 No. 2.

Kamus Besar Bahasa Indonesia Online. 2016. Didik. http://kkbi.web.id/didik Diakses tanggal12 November 2016.

Lubis, Arfan Ikhsan. Akuntansi Keperilakuan. Jakarta: Salemba Empat.

Martani, Dwi, Sylvia Veronica NPS, Ratna Wardhani, Aria Farahmita, dan Edward Tanujaya. 2014. Akuntansi Keuangan Menengah Berbasis PSAK. Jakarta: salemba Empat.

Nasution, Fakhrur Arifin. 2009. Pengaruh Kecerdasan Emosional Dan Kepercayaan Diri Terhadap Tingkat Pemahaman Akuntansi Mahasiswa UMSU. Jurnal Riset Akuntansi Dan Bisnis Vol. 9 No. 2.

Pidarta, Made. 2007. Landasan Kependidikan: Stimulus Ilmu Pendidikan Bercorak Indonesia. Jakarta: Rineka Cipta.

Suartana, I Wayan. 2010. Akuntansi Keperilakuan: Teori dan Implementasi. Yogyakarta: Penerbit Andi.

Tjun Tjun, Lauw, Santy Setiawan dan Sinta Setiana. 2009. Pengaruh Kecerdasan Emosional Terhadap Pemahaman Akuntansi Dilihat dari Perspektif Gender. Jurnal Akuntansi Vol.1 No.2.

Tu'u, Tulus. 2011. Cerdas Spiritualitas: Seimbang Spiritualitas dan Intelektualitas. Pabelum, Jurnal Teologi, Vol.3, No.1.

Undang - Undang Republik Indonesia. 2003. Undang - Undang Republik Indonesia Nomor 20 Tahun 2003 Tentang Sistem Pendidikan Nasional. http://buk.um.ac.id/wpcontent/uploads/2016/05/Undang-Undang-No-20-Tahun-2003-tentang-SistemPendidikan-Nasional.pdf diakses tanggal 12 November 2016.

Widyastuti, Wiwied. 2010. Pengaruh Kecerdasan Emosional, Kecerdasan Spiritual dan Budaya Organisasi Terhadap Perilaku Etis Auditor Pada KAP. Jurnal Multiparadigma, Vol.1, No.1.

Zohar, Danah dan Ian Marshall. 2002. SQ: Memanfaatkan Kecerdasan Spiritual dalam berpikir Integralistik dan Holistik untuk Memaknai Kehidupan. Bandung: Mizan.

Suwardjono. 2014. Teori Akuntansi: Perekayasaan Pelaporan Keuangan. Edisi Ketiga.

Yogyakarta: BPFE Universitas Gajahmada.

Riyanto, Yatim. 2010. Paradigma Baru Pembelajaran: Sebagai Referensi bagi Pendidik dalam Implementasi Pembelajaran yang Efektif dan Berkualitas. Jakarta: Kencana Prenada Media Group.

Purwanto, M. Ngalim. 2013. Psikologi Pendidikan. Bandung: Rosda. 